\title{
Moment redistribution in continuous prestressed concrete box girder with corrugated steel webs
}

\author{
Jin-Sheng $\mathrm{Du}^{1}$, Pui-Lam $\mathrm{Ng}^{2}$, Xiang $\mathrm{Ma}^{3}$, Jian Wang ${ }^{4}$

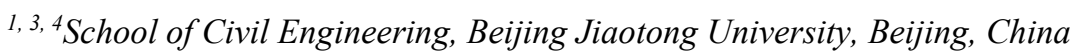 \\ ${ }^{2}$ Faculty of Civil Engineering, Vilnius Gediminas Technical University, Vilnius, Lithuania \\ ${ }^{2}$ Department of Civil Engineering, The University of Hong Kong, Hong Kong, China \\ E-mail:2irdngpl@gmail.com (corresponding author)
}

\begin{abstract}
A fibre-finite-element model of continuous prestressed concrete (PC) composite box girder with corrugated steel webs is established with force-based elements using OpenSees. After the model is validated with existing experimental data, the effects of reinforcement index in upper and lower flanges, effective prestress and concrete strength on the moment redistribution behaviour is analysed. It is shown that increasing the reinforcement index in lower flange or effective prestress can increase the amount of bending moment redistribution, whereas increasing the concrete strength or reinforcement index in upper flange can decrease the amount of bending moment redistribution. By inspecting the sensitivity of parameters, it is found that the reinforcement index in lower flange has the most significant influence on the moment redistribution, followed by the concrete strength and then by the effective prestress, while the reinforcement index in upper flange has only little impact on the moment redistribution. The calculation results are compared with the existing formulas. Finally, a moment redistribution formula is proposed for continuous PC box girder with corrugated steel webs.
\end{abstract}

Keywords: continuous box girder, corrugated steel webs, moment redistribution, prestressed concrete, OpenSees.

\section{Introduction}

Box girder with corrugated steel webs was invented in the 1980s by French engineers as an innovative and effective form of steel-concrete composite structural member (Cheyrezy \& Combault, 1990). It has the major advantages of relatively light self-weight, short construction time, good seismic performance, and desirable visual appearance (Sayed-Ahmed, 2001). Over the past years, vast research has been conducted on the flexural, shear, creep, fatigue and torsional behaviour of box girders with corrugated steel webs (Mo, Jeng, \& Chang, 2000; Au, Chen, Jiang, \& Huang, 2017). However, there has been little research on the behavioural aspect of bending moment redistribution (Ren, 2008).

In this paper, a bending moment redistribution model for continuous prestressed concrete (PC) box girder with corrugated steel webs is devised, with the use of OpenSees finite element software (Mazzoni et al., 2007) in carrying out numerical analyses. Sensitivity analysis of relevant parameters for moment redistribution in box girder with corrugated steel webs is conducted, and the analysis results are compared with the existing formulas. Lastly, a moment redistribution formula is proposed for continuous PC box girder with corrugated steel webs.

\section{Finite element simulation with OpenSees}

Fibre-finite-element model is defined in OpenSees software. In the computation approach, the uniaxial constitutive relationship of fibre element forms the basis of deriving the global stiffness matrix of a structural member. Such approach is computationally efficient and offers desirable accuracy. To-date, an universal simulation method of box girders with corrugated steel webs in OpenSees has not been established. In this study, multiple ways of simulating a box girder with corrugated steel webs have been explored, with the attempted use of various materials constitutive models and computation techniques available in OpenSees. By cross comparison of the numerical results with existing physical experimental results, the optimal simulation approach yielding satisfactory accuracy is identified. 


\section{Constitutive relationship of concrete}

Two constitutive relationship of concrete embedded in OpenSees, namely Concrete01 and Concrete02, have been used. These models are modified versions of Kent-Park model (Kent \& Park, 1971) by Scott, Park, and Priestley (1982). The confining effect of transverse reinforcement is accounted for by adjusting the peak compressive strength of concrete, the strain at peak compressive strength, and the gradient of compression softening. The residual strength of concrete is determined from the envelope curve of stress-strain relation. The tensile strength of concrete is neglected in Concrete01, while it is considered in Concrete02.

\section{Constitutive relationship of reinforcing steel}

Two constitutive relationship of reinforcing steel embedded in OpenSees, namely Steel01 and Steel02, have been used. These models are based on Giuffre-Menegotto-Pinto model (Giuffre \& Pinto, 1970; Menegotto \& Pinto, 1973). Steel01 is simple and does not take into account the Bauschinger effect of steel reinforcement (Gomes \& Appleton, 1997), while an additional parameter $R$ is introduced in Steel02 to account for the Bauschinger effect.

\section{Modelling of prestressing tendon}

To model the external post-tensioning tendon, the composite modelling approach (Zhu, 2004) is adopted, where fibre elements are used for modelling reinforced concrete, and truss elements are used for modelling prestressing tendon. They are connected through macro-elements to accommodate the relative displacements that occur upon loading, as illustrated in Figure 1 for a PC girder. The prestressing force is modelled by applying initial stresses to the associated elements.

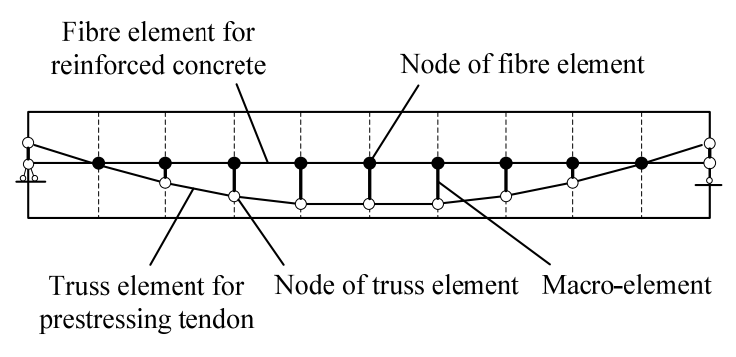

Figure 1. Element connectivity of model in OpenSees

\section{Equivalent representation of corrugated steel webs}

In contrast to a steel plate, the axial stiffness of a corrugated steel web is very small, while the shear stiffness is relatively large in resisting vertical shear force. In OpenSees, the corrugated steel web is modelled by setting the equivalent axial modulus to represent the axial stiffness in the longitudinal direction (Wan, Chen, Yuan, \& Yu, 2005; Wang, 2007) and setting the equivalent shear modulus to represent the shear stiffness of the corrugated steel material (Li \& Guo, 2001). The equivalent axial modulus $E_{x}$ is given by:

$$
E_{x}=\frac{t^{2}\left(a_{w}+b_{w}\right)}{d_{w}^{2}\left(3 a_{w}+c_{w}\right)} E_{0},
$$

where: $a_{w}$ - length of horizontal segment of corrugation; $c_{w}$ - length of inclined segment of corrugation; $b_{w}-$ projected length of $c_{w}$ on the horizontal line; $d_{w}$ - height of inclined segment of corrugation; $h$ - height of corrugated steel web; $t$ - thickness of steel web; $E_{0}$ - elastic modulus of steel plate.

The equivalent shear modulus $G_{e}$ is given by:

$$
G_{e}=\frac{a_{w}+b_{w}}{a_{w}+c_{w}} G_{s},
$$

where: $G_{s}$ - shear modulus of steel plate.

\section{Validation of finite element model}

A continuous PC box girder with corrugated steel webs tested by Qin (2010) is analysed to validate the finite element model. The girder was made up of two spans each of $6.0 \mathrm{~m}$ span length. A total of 9 steel diaphragms were provided along the length of girder. Two post-tensioned tendons of diameter $15.24 \mathrm{~mm}$ were installed and the level of prestress was $1395 \mathrm{MPa}$. Grade HRB355 steel reinforcement and grade A3 corrugated steel web with 2.35 mm thickness were used. During testing, loading was applied to both spans symmetrically. Figure 2 illustrates the cross-section of box girder specimen and the loading configuration. 


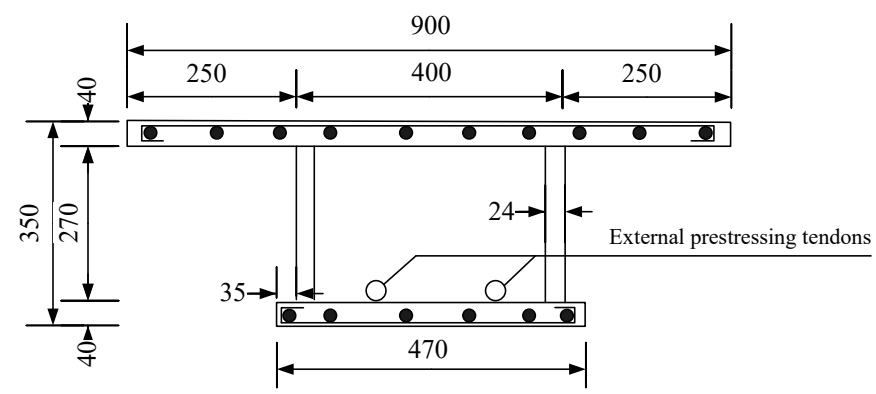

(a) Cross-section (unit: $\mathrm{mm}$ )

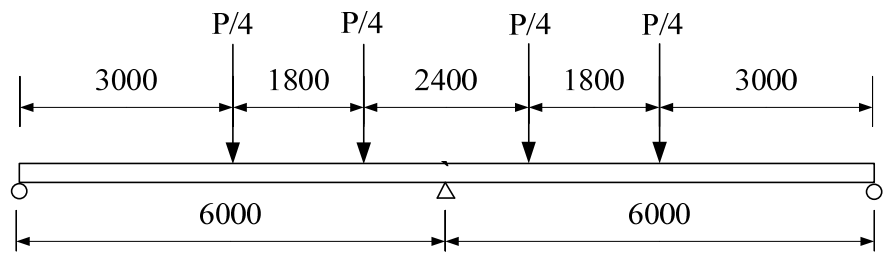

(b) Load configuration (unit: $\mathrm{mm}$ )

Figure 2. Cross-section and load configuration of continuous box girder specimen

Various finite element models are set up in OpenSees with different combinations of constitutive relationship of concrete, constitutive relationship of reinforcing steel, and element types, as summarised in Table 1. The element types include force-based (also referred to as flexibility-based) fibre elements (Mahasuverachai \& Powell, 1982) and stiffness-based (also referred to as displacement-based) fibre elements (Mari \& Scordelis, 1984) with different number of integration points. The results of numerical analyses are cross compared with the experimental result of box girder specimen, and are graphically depicted by the load-deflection curves in Figure 3 to Figure 5.

Table 1. Parameters of finite element models

\begin{tabular}{|c|c|c|c|}
\hline Model designation & $\begin{array}{c}\text { Constitutive } \\
\text { relationship of concrete }\end{array}$ & $\begin{array}{c}\text { Constitutive } \\
\text { relationship of steel }\end{array}$ & Element type \\
\hline $1-1-12$ & 1 (Concrete01) & 1 (Steel01) & 12 (forc., 2 IPs) \\
\hline $2-1-12$ & 2 (Concrete02) & 1 (Steel01) & 12 (forc., 2 IPs) \\
\hline $1-2-12$ & 1 (Concrete01) & 2 (Steel02) & 12 (forc., 2 IPs) \\
\hline $2-2-12$ & 2 (Concrete02) & 2 (Steel02) & 12 (forc., 2 IPs) \\
\hline $2-1-22$ & 2 (Concrete02) & 1 (Steel01) & 22 (stif., 2 IPs) \\
\hline $2-1-24$ & 2 (Concrete02) & 1 (Steel01) & 24 (stif., 4 IPs) \\
\hline $2-2-28$ & 2 (Concrete02) & 2 (Steel02) & 28 (stif., 8 IPs) \\
\hline
\end{tabular}

Note: 'forc.' and 'stif.' respectively stand for force-based and stiffness-based fibre elements; 'IPs' stands for integration points.

Figure 3 compares the numerical results with different constitutive relationship of concrete against the experimental result. From the figure, it can be seen that when Concrete01 is used, the flexural stiffness of the box girder in the elastic stage is lower than the experimental result; whereas when Concrete02 is used, the flexural stiffness is closer to the experimental result. Therefore, Concrete02 is chosen for adoption to model the concrete of upper and lower flanges of box girders.

Figure 4 compares the numerical results with different constitutive relationship of reinforcing steel against the experimental result. From the figure, it can be seen that when Steel01 or Steel02 is used, the resulting load-deflection curves are similar to each other and are in good match with the experimental result. In this study, Steel01 is adopted to model the reinforcing steel, whereas Steel02 is adopted to model the prestressing steel.

Figure 5 compares the numerical results of using force-based fibre elements with 2 integration points and of using stiffness-based fibre elements with 2, 4 or 8 integration points in the finite element model, against the experimental result. From the figure, it can be seen that when stiffness-based fibre element is used, the load-deflection curves deviate notably from the experimental result; whereas when force-based fibre element is used, the load-deflection curve is in good agreement with the experimental result even if only two integration points are present. Therefore, force-based fibre element with 2 integration points is chosen for adoption in the finite element simulation. 


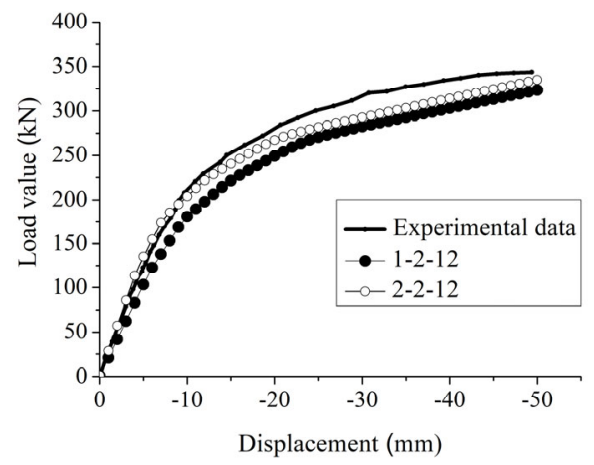

Figure 3. Load-deflection curves of models with different constitutive relationship of concrete

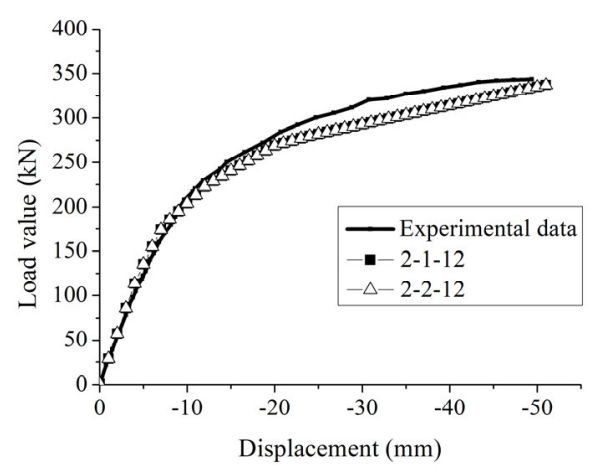

Figure 4. Load-deflection curves of models with different constitutive relationship of steel

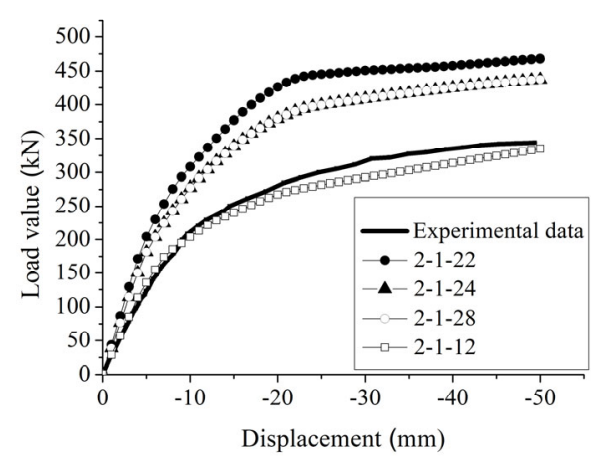

Figure 5. Load-deflection curves of models with different element types

\section{Sensitivity analysis}

With the adoption of the validated finite element modelling approach, and based on the reference two-span continuous PC box girder with corrugated steel webs analysed in the foregoing, sensitivity analysis of the influence of reinforcement index in upper and lower flanges, effective prestress and concrete strength on the bending moment redistribution is performed hereby. At this juncture, the reinforcement index $q_{s}$ is defined as:

$$
q_{s}=\frac{A_{s} f_{u}}{b_{f} h_{f} f_{c}},
$$

where: $A_{s}$ - area of steel reinforcement; $f_{u}$ - ultimate tensile strength of steel reinforcement; $b_{f}-$ breadth of upper or lower flange; $h_{f}$ - thickness of upper or lower flange; $f_{c}$ - compressive strength of concrete.

In the sensitivity analysis, the reinforcement index in upper flange varies among 0.10 and 0.20 , the reinforcement index in lower flange varies among 0.15 and 0.20 , the effective prestress varies among $0.5 f_{p u}$ and $0.6 f_{p u}$, where $f_{p u}$ is the ultimate tensile strength of the prestressing tendon, and the concrete strength grade (in $\mathrm{MPa}$ ) varies among $\mathrm{C} 40$, C45 and C60. A total of 14 analysis cases are considered and Table 2 lists the combinations of parametric values. 
Table 2. Sensitivity analysis of moment redistribution

\begin{tabular}{|c|c|c|c|c|c|c|c|}
\hline \multirow{2}{*}{$\begin{array}{l}\text { Analysis } \\
\text { case }\end{array}$} & \multirow{2}{*}{$\begin{array}{l}\text { Reinforcement } \\
\text { index at upper } \\
\text { flange }\end{array}$} & \multirow{2}{*}{$\begin{array}{l}\text { Reinforcement } \\
\text { index at lower } \\
\text { flange }\end{array}$} & \multirow{2}{*}{$\begin{array}{l}\text { Effective } \\
\text { prestress }\end{array}$} & \multirow{2}{*}{$\begin{array}{c}\text { Concrete } \\
\text { grade strength }\end{array}$} & \multicolumn{2}{|c|}{$\begin{array}{l}\text { Bending moment at } \\
\text { middle support }(\mathrm{kNm})\end{array}$} & \multirow{2}{*}{$\begin{array}{c}\beta \text {-value } \\
\text { at middle } \\
\text { support }\end{array}$} \\
\hline & & & & & $\begin{array}{c}\text { Before } \\
\text { redistribution }\end{array}$ & $\begin{array}{c}\text { After } \\
\text { redistribution }\end{array}$ & \\
\hline (1) & 0.10 & 0.10 & $0.5 f_{p u}$ & $\mathrm{C} 45$ & 378.26 & 330.67 & $12.58 \%$ \\
\hline (2) & 0.10 & 0.15 & $0.5 f_{p u}$ & $\mathrm{C} 45$ & 401.19 & 340.20 & $15.20 \%$ \\
\hline (3) & 0.10 & 0.20 & $0.5 f_{p u}$ & $\mathrm{C} 45$ & 424.33 & 349.77 & $17.57 \%$ \\
\hline (4) & 0.20 & 0.20 & $0.5 f_{p u}$ & $\mathrm{C} 45$ & 422.29 & 350.77 & $16.93 \%$ \\
\hline (5) & 0.20 & 0.15 & $0.5 f_{p u}$ & $\mathrm{C} 45$ & 400.11 & 341.26 & $14.71 \%$ \\
\hline (6) & 0.20 & 0.10 & $0.5 f_{p u}$ & $\mathrm{C} 45$ & 377.13 & 331.43 & $12.12 \%$ \\
\hline (7) & 0.20 & 0.20 & $0.6 f_{p u}$ & $\mathrm{C} 40$ & 393.28 & 319.87 & $18.67 \%$ \\
\hline (8) & 0.20 & 0.20 & $0.6 f_{p u}$ & C60 & 509.06 & 432.26 & $15.09 \%$ \\
\hline (9) & 0.20 & 0.15 & $0.6 f_{p u}$ & $\mathrm{C} 40$ & 370.29 & 310.27 & $16.21 \%$ \\
\hline (10) & 0.20 & 0.15 & $0.6 f_{p u}$ & C60 & 487.16 & 422.52 & $13.27 \%$ \\
\hline (11) & 0.20 & 0.20 & $0.5 f_{p u}$ & $\mathrm{C} 40$ & 390.83 & 319.82 & $18.17 \%$ \\
\hline (12) & 0.20 & 0.20 & $0.5 f_{p u}$ & $\mathrm{C} 60$ & 500.51 & 432.12 & $13.66 \%$ \\
\hline (13) & 0.20 & 0.15 & $0.5 f_{p u}$ & $\mathrm{C} 40$ & 368.07 & 310.08 & $15.76 \%$ \\
\hline (14) & 0.20 & 0.15 & $0.5 f_{p u}$ & C60 & 483.32 & 422.24 & $12.63 \%$ \\
\hline
\end{tabular}

To assess the influence of reinforcement index in upper flange, consider 3 pairs of analysis cases: $\{(1) \&(6)\}$, $\{(2) \&(5)\}$, and $\{(3) \&(4)\}$ from Table 2 . In each pair, only the value of $q_{s}$ in upper flange varies, while other parametric values remain constant. Comparison is based on the moment redistribution coefficient $\beta$. It is noted that as $q_{s}$ in upper flange increases, the moment redistribution coefficient decreased by an amount of $0.46 \%$ to $0.64 \%$.

On the other hand, to assess the influence of reinforcement index in the lower flange, consider 2 triplets of analysis cases: $\{(1) \&(2) \&(3)\}$ and $\{(4) \&(5) \&(6)\}$ from Table 2. In each triplet, only the value of $q_{s}$ in lower flange varies, while other parametric values remain constant. It is noted that as $q_{s}$ in lower flange increases, the moment redistribution coefficient increased by an amount of $4.81 \%$ to $4.99 \%$. Similarly, consider 4 pairs of analysis cases: $\{(7) \&(9)\},\{(8)$ $\&(10)\},\{(11) \&(13)\}$, and $\{(12) \&(14)\}$ from Table 2 . It is also seen that as $q_{s}$ in lower flange increases, the moment redistribution coefficient increased by an amount of $1.03 \%$ to $2.46 \%$. Compared to the reinforcement index in upper flange, the reinforcement index in lower flange exerts a larger influence on the flexural capacity and the moment redistribution.

To assess the influence of effective prestress, consider 4 pairs of analysis cases: $\{(7) \&(11)\},\{(8) \&(12)\},\{(9)$ $\&(13)\}$, and $\{(10) \&(14)\}$ from Table 2 . In each pair, only the effective prestress varies, while other parametric values remain constant. It can be seen that as the effective prestress increases, the moment redistribution coefficient increased by an amount of $0.45 \%$ to $1.43 \%$. It is understood that the effective prestress also affects the flexural capacity to a certain extent.

To assess the influence of concrete compressive strength, consider 4 pairs of analysis cases: $\{(7) \&(8)\},\{(9) \&$ $(10)\},\{(11) \&(12)\}$, and $\{(13) \&(14)\}$ from Table 2 . In each pair, only the concrete strength varies, while other parametric values remain constant. It can be seen that as the concrete strength increases, the moment redistribution coefficient decreased by an amount of $2.94 \%$ to $4.51 \%$. Compared to the effective prestress, the concrete strength exerts a larger influence on the flexural capacity and the moment redistribution.

From the above sensitivity analysis, it is observed that among the parameters studied, increase in reinforcement index in lower flange and increase in effective prestress lead to increase in moment redistribution coefficient; while increase in reinforcement index in upper flange and increase in concrete grade strength lead to decrease in moment redistribution coefficient. The factors influencing the magnitude of moment redistribution coefficient in the sequence of descending significance are: reinforcement index in lower flange, concrete grade strength, effective prestress, and reinforcement index in upper flange.

\section{Derivation of moment redistribution formula}

The existing moment redistribution formulas may be modified for application to PC box girder with corrugated steel webs. A collection of the formulas recommended in ACI 318M-11 (American Concrete Institute, 2011), Model Code 1990 (Comité Euro-International du Béton, 1993), BS 8110 (British Standards Institution, 1997), CSA-A23.3-04 (Canadian Standards Association, 2004), GB 50010-2010 (Ministry of Housing and Urban-Rural Development, 2010), Harbin Institute of Technology (HIT) (Zheng, Li, \& Wang, 2002) and Southeast University (SEU) (H. M. Lu \& 
Z. T. Lu, 1999) are listed in Table 3. From the tabulated formulas, it is seen that the moment redistribution coefficient is expressed in terms of the relative height of compression zone $\xi$, which is defined as the ratio of height of compression zone to the effective depth of flexural member.

Table 3. Moment redistribution formulas and calculation results

\begin{tabular}{|c|c|c|c|}
\hline Reference & Formula & $\begin{array}{l}\beta \text {-value obtained } \\
\text { from tabulated formula }\end{array}$ & $\begin{array}{l}\beta \text {-value obtained } \\
\text { from finite element analysis }\end{array}$ \\
\hline ACI $318 \mathrm{M}-11$ & $\beta \leq 0.2(1-2.36 \xi)$ & $6.45 \%$ & \multirow{7}{*}{$15.20 \%$} \\
\hline Model Code 1990 & $\beta=0.56-1.25 \xi \leq 0.25$ & $25.0 \%$ & \\
\hline BS 8110 & $\beta \leq 0.5-\xi \leq 0.2$ & $20.0 \%$ & \\
\hline CSA-A23.3-04 & $\beta \leq 0.3-0.5 \xi \leq 0.2$ & $16.8 \%$ & \\
\hline GB 50010-2010 & $\beta=0.2(1-2.5 \xi)$ & $6.80 \%$ & \\
\hline HIT & $\beta=0.4875-1.25 \xi$ & $15.75 \%$ & \\
\hline SEU & $\beta=0.45-\xi$ & $18.60 \%$ & \\
\hline
\end{tabular}

The formulas in Table 3 are applied to evaluate the moment redistribution coefficient for the analysis case (2) in Table 2, and the results are presented in the third column of Table 3. It can be seen that amongst all formulas, the moment redistribution coefficient obtained from HIT formula is the closest to the finite element analysis result. Therefore, the formula recommended by HIT is hereby modified, so as to improve the accuracy of the predicted $\beta$-value. The modified formula is proposed as:

$$
\beta=0.485-1.25 \xi \text {. }
$$

The proposed moment redistribution formula, i.e. Eq. (4), is applied to evaluate the $\beta$-values for different combinations of parameters as summarised in Table 4 . From the table, it is seen that the $\beta$-values so obtained are very close to the finite element analysis results, and the root-mean-square error is as small as $1.29 \%$. Therefore, Eq. (4) is sufficiently accurate to be recommended for practical evaluation of moment redistribution in continuous PC box girder with corrugated steel webs.

Table 4. Sensitivity analysis of moment redistribution

\begin{tabular}{|c|c|c|c|c|c|c|c|}
\hline \multirow{2}{*}{$\begin{array}{l}\text { Reinforcement } \\
\text { index at upper } \\
\text { flange }\end{array}$} & \multirow{2}{*}{$\begin{array}{c}\text { Reinforcement } \\
\text { index at lower } \\
\text { flange }\end{array}$} & \multirow{2}{*}{$\begin{array}{l}\text { Effective } \\
\text { prestress }\end{array}$} & \multirow{2}{*}{$\begin{array}{l}\text { Concrete } \\
\text { grade } \\
\text { strength }\end{array}$} & \multirow{2}{*}{$\begin{array}{c}\text { Relative height } \\
\text { of compression } \\
\text { zone }\end{array}$} & \multicolumn{2}{|c|}{$\beta$-value } & \multirow{2}{*}{$\begin{array}{l}\text { Root-mean- } \\
\text {-square } \\
\text { error }\end{array}$} \\
\hline & & & & & $\begin{array}{l}\text { Finite element } \\
\text { analysis }\end{array}$ & $\begin{array}{l}\text { Proposed } \\
\text { formula }\end{array}$ & \\
\hline 0.2 & 0.20 & $0.6 f_{p u}$ & $\mathrm{C} 40$ & 0.243 & $18.67 \%$ & $18.13 \%$ & \multirow{8}{*}{$1.29 \%$} \\
\hline 0.2 & 0.20 & $0.6 f_{p u}$ & $\mathrm{C} 50$ & 0.257 & $16.71 \%$ & $16.38 \%$ & \\
\hline 0.2 & 0.15 & $0.6 f_{p u}$ & $\mathrm{C} 40$ & 0.240 & $16.21 \%$ & $18.50 \%$ & \\
\hline 0.2 & 0.15 & $0.6 f_{p u}$ & $\mathrm{C} 50$ & 0.274 & $14.58 \%$ & $14.25 \%$ & \\
\hline 0.2 & 0.20 & $0.5 f_{p u}$ & $\mathrm{C} 40$ & 0.238 & $18.17 \%$ & $18.75 \%$ & \\
\hline 0.2 & 0.20 & $0.5 f_{p u}$ & $\mathrm{C} 50$ & 0.271 & $16.29 \%$ & $14.63 \%$ & \\
\hline 0.2 & 0.15 & $0.5 f_{p u}$ & $\mathrm{C} 40$ & 0.252 & $15.76 \%$ & $17.00 \%$ & \\
\hline 0.2 & 0.15 & $0.5 f_{p u}$ & C50 & 0.263 & $13.92 \%$ & $15.63 \%$ & \\
\hline
\end{tabular}

\section{Conclusions}

The present research encompasses the finite element simulation of prestressed concrete (PC) composite box girder with corrugated steel webs by using OpenSees software, sensitivity analysis of parameters influencing the bending moment redistribution of continuous PC box girder with corrugated steel webs, comparative study of moment redistribution coefficient evaluated from finite element analysis and from existing formulas, and derivation of moment redistribution formula. The following conclusions can be drawn: 
- The increase in reinforcement index in lower flange and increase in effective prestress lead to an increase in moment redistribution coefficient; while the increase in reinforcement index in upper flange and increase in concrete grade strength lead to a decrease in moment redistribution coefficient;

- The factors influencing the magnitude of moment redistribution coefficient in the sequence of descending significance are: reinforcement index in lower flange, concrete grade strength, effective prestress, and reinforcement index in upper flange;

- A new moment redistribution formula, modified from the formula proposed by Harbin Institute of Technology, is recommended for practical evaluation of moment redistribution in continuous PC box girder with corrugated steel webs.

\section{Acknowledgements}

This work was supported by Gansu Provincial Communications and Transportation Department of China [grant number 201607]; and the European Commission under the Marie Skłodowska-Curie Actions [grant number 751461].

\section{References}

American Concrete Institute. (2011). ACI Committee 318: Building Code Requirements for Structural Concrete (ACI 318M-11) and Commentary (ACI 318RM-11). Michigan, USA.

Au, F. T. K., Chen, X. C., Jiang, R. J., \& Huang, T. (2017). Full-range and long-term behaviour of prestressed concrete bridges with corrugated steel webs. Journal of Civil Engineering Research, 7(2), 35-45. https://doi.org/10.5923/j.jce.20170702.01

British Standards Institution. (1997). The Structural Use of Concrete: Part 1, Code of Practice for Design and Construction (BS 8110). London, UK.

Canadian Standards Association. (2004). Design of Concrete Structures (CSA-A23.3-04). Ontario, Canada.

Cheyrezy, M., \& Combault, J. (1990). Composite bridges with corrugated steel webs - achievements and prospects. In Proceedings, IABSE Symposium on Mixed Structures including New Materials. Brussels, Belgium.

Comité Euro-International du Béton. (1993). CEB-FIP Model Code 1990. London: Thomas Telford Ltd.

Giuffre, A., \& Pinto, P. E. (1970). Il comportamento del cemento armato per sollecitazioni cicliche di forte intensita. Giornale del Genio Civile, 5, 391-408.

Gomes, A., \& Appleton, J. (1997). Nonlinear cyclic stress-strain relationship of reinforcing bars including buckling. Engineering Structures, 19(10), 822-826. https://doi.org/10.1016/S0141-0296(97)00166-1

Kent, D. C., \& Park, R. (1971). Flexural members with confined concrete. Journal of the Structural Division, ASCE, 97(7), 19691990.

Li, S., \& Guo, Y. L. (2001). Study on shearing resistance beams with trapezoidally corrugated webs. Journal of Building Structures, 22(6), 49-54 (in Chinese). https://doi.org/10.3321/j.issn:1000-6869.2001.06.008

Lu, H. M., \& Lu, Z. T. (1999). Study of moment modification of partially prestressed concrete hyperstatic structures. Journal of Southeast University, 29(2), 70-75 (in Chinese). https://doi.org/10.3321/j.issn:1001-0505.1999.02.014

Mahasuverachai, M., \& Powell, G. H. (1982). Inelastic analysis of piping and tubular structures (Report No. UCB/EERC-82/27). University of California, Berkeley, USA.

Mari, A. R., \& Scordelis, A. C. (1984). Nonlinear geometric, material and time dependent analysis of three dimensional reinforced and prestressed concrete frame (SESM Report 82-12). Department of Civil Engineering, University of California, Berkeley, USA.

Mazzoni, S., McKenna, F., Scott, M. H., \& Fenves, G. L., et al. (2007). OpenSees command language manual. Pacific Earthquake Engineering Research (PEER) Center, USA.

Menegotto, M., \& Pinto, P. E. (1973). Method of analysis for cyclically loaded R.C. plane frames including changes in geometry and non-elastic behaviour of elements under combined normal force and bending. In Proceedings, IABSE Symposium on Resistance and Ultimate Deformability of Structures Acted on by Well Defined Repeated Loads. Lisbon, Portugal.

Ministry of Housing and Urban-Rural Development (MOHURD) of the People's Republic of China. (2010). Code for Design of Concrete Structures (GB 50010-2010). China Architecture \& Building Press, Beijing, China.

Mo, Y. L., Jeng, C. H., \& Chang, Y. S. (2000). Torsional behavior of prestressed concrete box-girder bridges with corrugated steel webs. ACI Structural Journal, 97(6), 849-859.

Qin, Z. (2010). Experimental study on ultimate capacity of composite continuous girders with corrugated steel webs (Master thesis). Hunan University, Changsha, China (in Chinese). https://doi.org/10.7666/d.y1724104

Ren, H. W. (2008). Experimental study on prestressed concrete box-girders with corrugated steel webs under symmetrical loads. Journal of the China Railway Society, 30(1), 60-64 (in Chinese). https://doi.org/10.3321/j.issn:1001-8360.2008.01.011

Sayed-Ahmed, E. Y. (2001). Behaviour of steel and (or) composite girders with corrugated steel webs. Canadian Journal of Civil Engineering, 28(4), 656-672. https://doi.org/10.1139/101-027

Scott, B. D., Park, R., \& Priestley, M. J. N. (1982). Stress-strain behavior of concrete confined by overlapping hoops at low and high strain rates. ACI Structural Journal, 79(1), 13-27. 
Du, J.-Sh.; Ng, P.-L.; Ma, X.; Wang, J. 2019. Moment redistribution in continuous prestressed concrete box girder with corrugated steel webs

Wan, S., Chen, J. B., Yuan, A. H., \& Yu, W. B. (2005). Experimental study and predigestion calculate of prestressed concrete boxgirder with corrugated steel webs. Journal of East China Jiaotong University, 22(1), 11-14 (in Chinese). https://doi.org/10.3969/j.issn.1005-0523.2005.01.004

Wang, F. (2007). Experimental study on mechanical behavior of composite box-girder with corrugated steel webs (Master thesis). Hunan University, Changsha, China (in Chinese). https://doi.org/10.7666/d.d031348

Zheng, W. Z., Li, H. P., \& Wang, Y. (2002). Plastic design of statically indeterminate prestressed concrete structures. Harbin, China: Harbin Institute of Technology Press (in Chinese).

Zhu, Z. (2004). Joint construction and seismic performance of concrete-filled fiber reinforced polymer tubes (Master thesis). North Carolina State University, North Carolina, USA. 